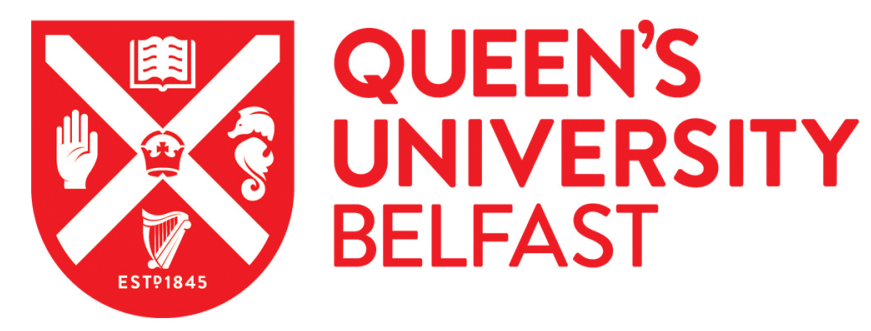

\title{
The Future of Northern Ireland: Border Anxieties and Support for Irish Reunification under Varieties of UKEXIT
}

Garry, J., O'Leary, B., McNicholl, K., \& Pow, J. (2020). The Future of Northern Ireland: Border Anxieties and Support for Irish Reunification under Varieties of UKEXIT. Regional Studies.

https://doi.org/10.1080/00343404.2020.1759796

Published in:

Regional Studies

Document Version:

Peer reviewed version

Queen's University Belfast - Research Portal:

Link to publication record in Queen's University Belfast Research Portal

Publisher rights

Copyright 2020 Taylor and Francis. This work is made available online in accordance with the publisher's policies. Please refer to any applicable terms of use of the publisher.

\section{General rights}

Copyright for the publications made accessible via the Queen's University Belfast Research Portal is retained by the author(s) and / or other copyright owners and it is a condition of accessing these publications that users recognise and abide by the legal requirements associated with these rights.

Take down policy

The Research Portal is Queen's institutional repository that provides access to Queen's research output. Every effort has been made to ensure that content in the Research Portal does not infringe any person's rights, or applicable UK laws. If you discover content in the Research Portal that you believe breaches copyright or violates any law, please contact openaccess@qub.ac.uk. 


\section{The Future of Northern Ireland:}

\section{Border Anxieties and Support for Irish Reunification \\ under Varieties of UKEXIT}

\section{Introduction}

The secession of a multi-national state from a confederation is inevitably troublesome. The difficulties may be manageable when the secessionist state's borders are uncontested, but if the land border between the secessionist state and the rest of the confederation runs across a deeply divided region negotiating the exit is likely to be complex and acrimonious, especially for the public in the region.

We focus here on the United Kingdom's prospective exit from the European Union (UKexit). The sole land border that will arise is that between one constituent part of the multi-national UK, Northern Ireland, and Ireland, also known as the Republic of Ireland. That border, sometimes called the 'north-south border,' has its contested origins in a colonial partition, has been the focus of violent ethno-national conflict and has never had significant popular support among one section of the affected population (O'Leary 2019a, Leary 2016, O'Leary 2019c). The border's political salience had radically declined in recent times, however, because of a remarkable political settlement, namely, the 1998 Belfast/Good Friday Agreement (Todd 2003, McGarry 1998, 2001). This settlement, and its successors, combined elements of consociational and confederal statecraft (O'Leary 2019b). The June 2016 referendum in the UK, in which UK citizens voted to leave the union by a $52: 48$ margin, whereas Northern Ireland voted to remain by a margin of $56: 44$, instantly revived 
controversy over the border, and revived debate over the constitutional future of Northern Ireland and attitudes to Irish re-unification.

Here we empirically examine how the public in Northern Ireland viewed the potential hardening of the border between Northern Ireland and the Republic of Ireland as a result of UKexit, and how their border-related concerns affected levels of support for Irish unification. We use complementary qualitative and quantitative data, derived from a specially designed one-day Citizens' Assembly and a distinct population-wide survey of citizens' attitudes.

In our analysis we distinguish not only between the two major communities in Northern Ireland, cultural Catholics and cultural Protestants, but also identify sub-groups of Catholics. Consistent Catholics have views that are constant, irrespective of the outcome of UKexit. Conditional Catholic nationalists, by contrast, support Irish re-unification, but only under 'hard exit' conditions, i.e., circumstances in which the UK as a whole, including Northern Ireland, leaves the EU, including its customs union and single market. Switching to support reunification among this sub-group of Catholics under hard exit conditions is strongly driven by their views about the border, and especially their willingness to support protests against any possible emergent hard north-south border. We therefore demonstrate that public attitudes in Northern Ireland to the constitutional future of the region are conditioned by developments relating to the border and the nature of the UK's exit from the EU.

The paper is organised as follows. We elaborate our research questions in the context of our examination of the UK's prospective secession from the EU and the central role of the northsouth land border in the UK-EU negotiations. We then describe our data. Next, we report 
our results: we examine public attitudes to the border and assess how such attitudes explain potential support for a united Ireland under different conditions of UK exit, highlighting the role of conditional Catholic nationalists. We conclude by elaborating the implications of our findings in the context of the passage of the Withdrawal Agreement negotiated by Prime Minister Johnson and its Northern Ireland Protocol, and the impending future relationship negotiations between the EU and the UK. Broader lessons are then considered.

\section{UKEXIT, the border and potential support for Irish unity}

The vote across the United Kingdom and Gibraltar to leave the European Union in the June 2016 referendum brought into sharp focus the politics of one of the UK's four component parts - Northern Ireland (O'Leary 2016). Proportionally, Northern Ireland had voted more decisively to remain within the EU than Great Britain had voted to leave, but the result was interpreted by the Conservative government as binding on all four components of the Union of Great Britain and Northern Ireland.

Quite unexpectedly for many 'Brexiteers' the question of 'the Irish border,' or, as some prefer to style it, the British (or UK) border in Ireland, dominated the UK-EU negotiations that formally began when the UK triggered Article 50 of the Treaty on European Union in March 2017. ${ }^{1}$ Under Theresa May’s leadership, the UK initially announced several "red lines," including its determination to leave the customs union (CU) of the European Union, and the regulatory structure of the European single market (SM) that is policed by the Court of Justice of the European Union (CJoEU). These "red lines" appeared incompatible with

\footnotetext{
${ }^{1}$ For a detailed account of the negotiations see Connolly (2018), for an economic historian's perspective see O'Rourke (2019), for an historical account of the border see Ferriter (2019), and for an overview of the implications for Northern Ireland see Murphy (2018).
} 
two other related pledges made by the prime minister: to protect the Good Friday Agrement (incorporated by treaty with Ireland) 'in all its parts,' and to avoid a hardening of the border between Northern Ireland and the Republic of Ireland.

The provisions of the Good Friday Agreement, partly embedded in UK law in the Northern Ireland Act (1998), require the Northern Ireland Assembly to act in accordance with EU law (Section $6(2)$ d). The cross-border arrangements, embedded in binding international treaties (the British-Irish Agreement(s) of 1999) that protect the Good Friday Agreement, require the North-South Ministerial Council, which brings together Dublin and Belfast ministers, to engage in cooperation on relevant EU matters that are cross-border or all-island in nature, and they have helped create an all-island market within the European SM, notably, but not only, in electricity and agri-food business (Government of the United Kingdom 1998, Strand Two: 3 (iii), 17, and Annex 8). The peace provisions in the Good Friday Agreement required the demilitarization of the border, and its implementation was tangible proof of the success of the peace process. The range of UK-Ireland agreements related to Northern Ireland - the Anglo-Irish Agreement (1985), the Joint Declaration for Peace (1993) through to the BritishIrish Agreement(s) (1999) - had emphasized both sovereign states' partnership within the European Union, which is now expected to end. Furthermore, both governments had pledged themselves to the equivalent protection of human and minority rights across the island, including new rights pledged in the Good Friday Agreement, and rights under the jurisdiction of both the CJoEU and the European Court of Human Rights and Fundamental Freedoms (Government of the United Kingdom 1998, Strand One, Rights, Safeguards and Equality of Opportunity: 2, 5(b), 26(a)). 
May's "red lines," removing the European underpinning of the Good Friday Agreement, appeared to threaten a hardening of the north-south border because if the entire UK leaves the CU, then a customs border has to re-materialize on the island of Ireland. Since 1973, when the UK and Ireland jointly entered the then European Communities, there has been no need for customs checks on cross-border traffic across the island. Abandoned and decaying customs posts and offices can be seen by astute travellers. Fresh customs infrastructure would not only damage the concept of 'a borderless Ireland within a borderless Europe' ${ }^{2}$ but also would create fixed targets for hitherto marginalized militant Irish republicans - who hope to revive the long war ended by the IRA's compliance with the Good Friday Agreement. Likewise, if the entire UK leaves the SM (or diverges from it) then regulatory barriers to goods and services have to re-materialize on the island and between the two major islands in the British and Irish archipelago.

During the negotiations, a compromise emerged to avoid a hardening of the north-south border. It implied a differentiated UK exit from the EU, whereby Northern Ireland would be treated differently to Great Britain, leading to the creation of an economic border between Northern Ireland and Great Britain, often called a border down the Irish Sea. In December 2017 the May government agreed with the European Union's negotiators, led by Michel Barnier, that, absent or until a technological solution (widely judged impossible in the short term), the customs and regulatory border between Great Britain and the European Union would be administered at ports and airports, effectively running through the Irish Sea, making Northern Ireland a truly distinctive region - one subject to EU law, consistent with

\footnotetext{
${ }^{2}$ This was a favored theme of John Hume, former leader of the moderate Irish nationalists in the Social Democratic and Labour Party (SDLP), and one of the architects of the peace process, and the Good Friday Agreement (see discussion in McLoughlin, 2013).
} 
the Good Friday Agreement, for certain purposes, and yet a full component part of a nonmember state, the UK, for all other purposes. Despite the potential advantages of this proposal for Northern Ireland, not least in its comparative administrative ease, it was unacceptable to the leaders of the Democratic Unionist Party (DUP) and their hard-line supporters in Great Britain. The DUP, then in a 'supply and confidence' agreement with the minority Conservative government, insisted that Northern Ireland should not be treated differently from any other part of the UK (even though Northern Ireland is treated differently in many other respects, not least in the provisions of the Good Friday Agreement and its supplements). The DUP and its allies in the European Research Group (ERG), the organization of anti-EU Conservatives MPs, accused the EU (and Ireland) of seeking to annex Northern Ireland, by implication accusing May of treason. Some claimed that the draft provisions violated the 'principle of consent,' namely, that there will be no change in Northern Ireland's status as part of the UK without the consent of a majority of its people, although most observers agree that the principle of consent applies solely to whether Northern Ireland is to be part of the UK or sovereign Ireland. ${ }^{3}$

May could not ignore the views of the DUP because since the summer of 2017 election her minority Conservative administration was dependent upon the DUP to survive votes of confidence in the Westminster parliament. Having tried to bypass the DUP in December 2017, in order to reach an agreement with Barnier, May felt obliged to accommodate the views of her DUP allies given their overt rejection of the initialed text. In a volte-face, still frequently misunderstood, May then renegotiated the provisions regarding what became

\footnotetext{
${ }^{3}$ For example, see the exchange between Sammy Wilson, DUP "Brexit" spokesperson and Lady Hermon in the Northern Ireland Affairs Committee, 6 March 2019. See also, $\underline{\text { https://blogs.lse.ac.uk/politicsandpolicy/brexit-good-friday-agreement/ }}$
} 
called 'the Irish backstop' element of the Withdrawal Agreement - in effect keeping the whole of the UK within a new customs union with the EU, and in regulatory alignment with the EU, until a future agrement is made between the UK and EU, or until such time as future technological transformations, or free trade and legal agreements render "the Irish backstop" unnecessary. What the backstop effectively impled was a binding legal agreement to prevent fresh physical infrastructure on the island of Ireland, thereby keeping Northern Ireland (and Great Britain) in the equivalent of the $\mathrm{CU}$ and the SM sine die - that is, unless and until a new agreement is reached between the UK and the EU. It also protected North-South cooperation and the rights regimes established under the Good Friday Agreement. Both Ireland and the EU would share a veto on the UK's withdrawal from the backstop, and thereby, among other matters, constrain its ability to make free trade agreements with third parties.

The leading party of Ulster unionism, the DUP, supported leaving the EU, but insisted that Northern Ireland's departure should be on the same terms as Great Britain, demanding the removal or replacement of 'the backstop.' Until the last moment the party supported the possibility of a 'no deal' exit, which would have implied the restablishment of north-south border controls. In late March 2019, however, the party's deputy leader Nigel Dodds, signaled that the party would prefer remaining in the EU to any deal which contained the backstop arrangements. The leading party of Irish nationalism within Northern Ireland, Sinn Féin, has, by contrast, supported the Irish government in its determination to avoid any possibility of the re-erection of a hard border across Ireland. ${ }^{4}$ Sinn Féin has demanded a socalled 'border poll' - a referendum in Northern Ireland on whether to stay in the UK or unify with the rest of Ireland (and thereby rejoin the EU). It is the duty of the UK's Secretary of

\footnotetext{
${ }^{4}$ On the history of the differences between the DUP and Sinn Féin on the EU question see Ganiel (2013) and Maillot (2013).
} 
State for Northern Ireland to decide whether or not to iniatiate a referendum and to base the decision on whether or not there is evidence that the public would support re-unification.

Overall, the questions related to the 'Irish border' have been central to UK's attempted exit, and - equally - UK's exit has raised the salience of the politics of the Irish border. The net effect of this symbiosis has revived debate about the constitutional future of Northern Ireland. These facts frame our empirical investigation of public opinion in Northern Ireland on matters relating to the north-south border, the UK's exit and Northern Ireland's constitutional future. We aimed to answer two questions:

1. What was the public's attitudes to possible changes to the north-south border as a result of UKEXIT?

2. To what extent was public concern over a possible hardening of the northsouth border a determinant of increased support for Irish unification?

\section{Data}

To address these questions, we deploy two sources of data. First, we draw upon qualitative data from citizens' discussions in a deliberative forum (citizens' assembly) we organised to consider the impact on Northern Ireland of the UK's decision to leave the EU. ${ }^{5}$ We invited forty-eight people from across Northern Ireland to take part in a day of presentations and discussion about the possible impact on Northern Ireland of the UK's exit from the EU. This

\footnotetext{
5 Citizens' Assemblies have been formally instituted by a number of states to consider, and make, recommendations on public policy questions. There have also been many research exercises resembling ours (see for example: Farrell, 2014; Farrell et al., 2019; Fournier et al. 2011; and Fishkin, 2018). We transcribed the citizens' roundtable discussions which occurred after expert presentations by two of the authors and we analysed the text to identify emerging themes.
} 
forum took place on 10 February 2018 at the Clayton Hotel in Belfast. We commissioned Ipsos MORI Northern Ireland to select the 48 participants to be broadly representative of the Northern Ireland population in their socio-demographic backgrounds and geographic residences. Importantly, the sample was broadly balanced between those who had voted Leave and those who had voted Remain in the 2016 referendum. The 48 participants comprised the following: 23 males and 25 females; 13 18-29 year-olds, 11 30-44 year-olds, 12 45- 59 year-olds, and 12 60+ year-olds; 28 middle class participants (ABC1) and 20 working class (C2DE) participants; 8 from Belfast City, 10 from Greater Belfast, 7 from County Down, 4 from County Armagh, 6 from County Tyrone/Fermanagh, 6 from County Derry/Londonderry and 7 from County Antrim; 21 Catholics, 22 Protestants and 5 from neither community background; 23 voted to Leave in the 2016 referendum, 21 voted to Remain, and 4 did not vote.

Second, we draw on quantitative survey data. Ipsos MORI Northern Ireland was commissioned to ask our questions in a survey of the attitudes of a representative sample of the Northern Ireland population: 1,012 people from across the region were interviewed in their home in face-to-face computer-assisted interviews between 9 February and 12 March 2018. A two-stage sampling design was used, with random selection of geographic sampling points and quotas set for each sampling point based on the latest socio-demographic census estimates, to ensure that the respondents were statistically representative of the Northern Ireland population regarding traits such as age, gender, religion of origin, geographical location, and social class. In our survey we asked batteries of questions about the border and about support for a united Ireland under different exit conditions, as well as questions on a number of party-related and social issues. 


\section{What are the public's attitudes to possible changes to the north-south border?}

We begin by examining the discussions of citizens participating in our Citizens' Assembly $(n=48)$. We then focus on examining the quantitative data from our attitude survey of a representative sample of the Northern Ireland population $(n=1012)$

\subsection{Qualitative evidence from a citizens' assembly}

In our facilitated discussion in the deliberative forum on the possibility of a hardening of the border between Northern Ireland and the Republic of Ireland because of the UK's exit from the EU, a range of themes emerged from the participants structured dialogue. The first was a concern that hardening would represent a regress; it prompted images of a heavily policed border, challenging to implement, with citizens feeling intimidated. It would be 'a disaster' and 'a nightmare'.

"I could see it going the way it was before... Roads being closed off in various places because they can't properly police it."

Female, 60+, ABC1, Protestant, Remain

"I think it would be a disaster, I really do. It would be back to the days when traffic was queued up to try and get across the border, and the police were there, the army was there. I mean, you felt very intimidated by it all no matter which side of the border you were coming from."

Female, 60+, C2DE, Catholic, Remain

"It would be a nightmare, I think that's going back in time."

Male, 30-44, ABC1, Catholic, Remain

The potential for everyday inconvenience was voiced by participants: simple matters of quotidian travel for shopping, leisure, and to see one's family. Fears were expressed that accepted current ease of travel could be negatively affected and would be detrimental. 
"... half my family is from the South and half my family is from the North, and the last thing that I bloody want is to go across the border with my passport to visit my granny."

Male, 18-29, ABC1, Catholic, Remain

“... I would go to the Slieve Russell [a hotel] all the time and it's over the border. You know, if you're wanting to just go to the spa or go for something to eat, do I need to bring my passport? ... What about normal day-to-day stuff? Say I want to walk the dog. I'm literally 10 minutes across the border. It would be a nightmare."

Female, 18-29, ABC1, Catholic, did not vote

"Where my parents live, it's half a mile to the nearest shop in Derry and half a mile to the nearest shop in Muff in Donegal, but you would go to Muff because the diesel is cheaper, and it would be a back and forth through customs and getting stopped. I cross the border on a daily basis." Male, 30-44, ABC1, Catholic, Remain

One widely discussed possible change in the event of a hardening of the border is the potential use of 'technology,' including cameras, to check and track cross-border travel. For some participants this was an acceptable and unobtrusive development given the current prevalence of such devices.

"Cameras wouldn't annoy me; CCTV is everywhere in Northern Ireland." Male, 18-29, ABC1, Catholic, Remain

"If they could do it with just cameras that would be fine." Male, 45-59, Protestant, Leave

However, for other participants, new camera technology would pose a threat because it would likely attract a reaction from people opposed to any border infrastructure. This reasoning led some to predict cameras would be vandalised or attacked.

"If there's ever going to be a hard border it will be security cameras mainly, it will be mainly in the border areas. I mean, they paint over the signs. They'll vandalise the signs. The cameras will have to be about 300 feet in the air. And even then... you will get certain people who take the law onto themselves and cut these things down. So, to lessen it, it would have to be the softest hardest border. Military checkpoint is a no-no. Cameras, that would be a no-no as well..."

Male, 45-59, ABC1, Catholic, Remain 
"I can see vandalism because even on the main road there from Derry to Belfast and you've even the Londonderry sign scored out. So, what's the chances of a camera getting graffitied over? Sure, it's just another item to destroy like."

Male, 18-29, ABC1, Catholic, Remain

The potential for more widespread violent protest was highlighted by many. The development of a hard border was seen as increasing the likelihood of paramilitary attack, especially when Northern Ireland's politics remains 'volatile'. Participants raised the prospect of violent reaction if the police or army were deployed to protect customs officials.

“...then you're bound to get terrorists, then you get terrorists jumping on the bandwagon then ... we don't have that many people getting killed but with a border then we're back to normal again ... this country at the minute is volatile enough, I think that it would take very little for the whole thing to start up again whether people back it or not"

Female, 60+, ABC1, Catholic, Remain

"I think if there was police or army, it's not going to be the customs people. Because the customs people fear for their lives, so it'll be police and army. And adding that into the equation, you're just lighting the spark."

Female, 60+, ABC1, Catholic, Remain

"I think the ceasefire would go."

Male, 45-59, C2DE, Protestant, Leave

A small number of participants (typically Leave-voting Protestants) were unconcerned about potential changes to the border, and felt they were reasonable and uncontroversial developments.

"It wouldn't annoy me about the border. It wouldn't annoy me at all. We had it years ago, and also too I go to Spain and Gibraltar; it's exactly the same."

Female, 60+, C2DE, Protestant, Leave

"Sure, if you go to America or Canada, you've to go through a border there anyway."

Female, 60+, C2DE, Protestant, Leave 


\subsection{Evidence from a survey of public attitudes}

This discursive data is complemented by our quantitative evidence that allows for more systematic generalisation to the affected population. We first assessed the extent to which the Northern Ireland population find the prospect of north-south border changes problematic. We invited respondents to indicate whether they would find a range of border checks as 'almost impossible to accept' or 'would not like it but could live with it if I had to' or 'I would happily accept this'. We offered a range of border-check scenarios.

\section{$<<$ Figure 1 about here $>>$}

Significant proportions of the Northern Ireland population find changes to the north-south border almost impossible to accept, with opposition greater among Catholics than Protestants (see Figure 1 for Catholic-Protestant differences). The proportion of the population regarding cameras as almost impossible to accept is 14 per cent (rising to 20 for Catholics) and 30 per cent for drones (rising to 42 per cent for Catholics). Between 41 and 54 per cent of all respondents regard the following as almost impossible to accept: checkpoints with customs officials; the Police Service of Northern Ireland (PSNI) manning checkpoints; British soldiers, Gardaí (Irish police) or Irish soldiers manning checkpoints; being required to produce a passport at the border; border checks that would add 30 minutes to your journey; and having your photograph taken or your fingerprints checked or any other biometric testing. Catholic respondents are particularly opposed, with between 55 per cent and 72 per cent finding these types of checks almost impossible to accept. The idea of having to apply in advance for travel documents is perceived as particularly objectionable: 69 per cent of the population would find this almost impossible to accept, including 80 per cent of Catholics. 
Respondents were asked whether and to what extent they would have sympathy or support for "possible forms of protest against any new border checks or controls between Northern Ireland and the Republic of Ireland.” If people who are opposed to a North-South border engaged in signing a petition or a peaceful demonstration, 60 per cent of all respondents would have either "a fair amount of sympathy with this and would support it" or "a lot of sympathy with this and would support it a lot" (with substantially more support among Catholics than Protestants: see Figure 2). This proportion falls to 15 per cent when the type of protest involves protestors blocking traffic. However, almost a quarter of Catholics (22.2 per cent) would still be fairly or very supportive. Only 5 per cent of the population as a whole would be fairly or very supportive of vandalising border technology, such as cameras. However, almost one in 10 Catholics (9.2 per cent) would support this kind of vandalism.

Thus far we have reported qualitatively and quantitatively on the nature and extent of public (and particularly Catholic) concerns about any possible hardening of the north-south border that may result from the UK's exit from the EU. We now seek to investigate the potential implications for such border concerns for people's view of the constitutional future of Northern Ireland. Has the emergence of significant border concerns triggered a desire to eradicate the border entirely and generate a united Ireland?

\section{Border concerns and support for unificiation under 'hard exit' conditions}

Would there be an increase in support for Irish unification under conditions of a 'hard exit' by the UK from the EU, and is this increase driven by concerns about potential north-south border changes? We begin by examining support for unification under different exit 
scenarios, identifying a group of 'conditional Catholic nationalists' (CCNs), we then assess the extent to which it is border concerns that drive these CCNs, first in a bivariate analsyis and then in a model incorporating a range of other possible predictors.

\subsection{Is support for a united Ireland conditional upon different types of UKEXIT?}

We sought to assess the extent to which attitudes to the constitutional future of Northern Ireland are related to the fact and potential nature of the UK's exit from the EU. We asked respondents in the survey to indicate how they would vote in a referendum in which the choice was between Northern Ireland staying in the UK or re-joining the rest of Ireland in a united Ireland. We asked respondents to indicate their preference under a range of different conditions. Our main interest was in discerning how changeable support is for a united Ireland under different UK exit conditions. We were particularly seeking to identify whether the prospect of a so-called 'hard Brexit' (defined in the survey as the entire UK leaving the EU, including leaving the $\mathrm{SM}$ and the $\mathrm{CU})^{6}$ prompts an increase in support for a united Ireland compared to the UK remaining in the EU. The biggest difference (as shown in Figure 3) occurs among cultural Catholics, whose support for a united Ireland was 27.5 percent under 'Remain in EU' conditions, but 53 percent under 'Hard UK Brexit' conditions — albeit with a very large 'don't know' proportion of almost equal size (approx. 30 percent) under each condition.

$<<$ Figure 3 about here $>>$

\footnotetext{
${ }^{6}$ In the deliberative forum these concepts were carefully and neutrally explained; in the survey we are confident that the significance of the customs union and the single market were widely understood because of their prominent public salience since the summer of 2016.
} 
This difference, a doubling in support for reunification, is almost as large as the speculative financial comparison we also included, in which a united Ireland may leave the respondent either $£ 3,500$ worse off or better off. A positive pay-off increases support for a united Ireland from 22 percent to 55 percent. The financial comparison prompts the greatest difference among Protestants, when compared with other scenarios, with support for staying in the UK declining from 82 percent to 72 percent, whereas the directly Brexit-related comparison results in a relatively small shift (a five percentage point drop). Among the overall population what was noteworthy was a 15 point shift in overall support for staying in the United Kingdom when strongly contrasting scenarios were offered. Remaining in the EU commanded 64 per cent support, whereas a hard UK-wide exit leads to support for staying in the UK to slip just below the critical 50 percent mark (to 49 percent). In the provisions of the Good Friday Agreement support at fifty per cent plus one of those voting in a valid poll is sufficient to determine a change in the status of Northern Ireland, provided that is matched by an equivalent result in the Republic of Ireland.

Crucially, we are able identify a sizeable potential UKEXIT-inspired split in the Northern Ireland Catholic population: namely, Catholics who are practical 'unionists' under 'UK Remains in EU' conditions, but who favour a united Ireland under 'UK-wide hard exit from EU' conditions. We label them (as noted) conditional Catholic nationalists (CCNs) - they may perhaps be compared to the 'soft nationalists' identified by analysts of Quebec and Catalonia (Young 1995, Lluch 2014). We now investigate what exactly drives these CCNs, and begin by assessing the extent to which their potential support for a united Ireland is directly driven by their concerns over what may potentially happen to the north-south border in the event of a 'hard Brexit.' 


\subsection{Is conditional Catholic United Irelandism driven by border concerns?}

To simplify analysis we create a single variable that captures the extent to which Catholics feel that border changes are almost impossible to accept. In relation to each of the 12 possible changes illustrated in Figure 1 we code respondents as ' 1 ' if they regard each change as almost impossible to accept and ' 0 ' if they do not so regard it. We then sum the resulting variables, creating a single variable running from 0 (people who do not find any of the 12 possible changes as impossible to accept) to 12 (they find all of them impossible to accept). We similarly create a single variable scale which represents the number of types of protest against a potential hard border the respondent would be supportive of ( 0 if they do not support any of the 6 types of protest and 6 if they are supportive of all 6 types).

$<<$ Figure 4 about here $>>$

$<<$ Figure 5 about here $>>$

Figures 4 and 5 show that conditional Catholics (the yellow bar in each graph) have relatively high scores on each scale and in each graph their scores are statistically indistinguishable from the scores of consistent Catholic nationalists who are consistently pro-united Ireland. Similarly, the scores of the conditional Catholics are higher in both graphs than those Catholics who consistently prefer Northern Ireland to stay in the UK. What these graphs suggest is that the portion of the Catholic community that supports staying in the UK under normal conditions (i.e. with the UK being in the EU) is split in terms of whether it would potentially support a united Ireland under hard UK-exit conditions, and that the driver of this split is variation in the extent to which Catholics find border changes impossible to accept and support protest against them. Differently put, there are 'sleeper' pro-united Ireland 
Catholics whose potential reunification identification is demonstrably likely to be triggered by border concerns.

\subsection{A model of potential Catholic support for Irish unification}

We now develop a more comprehensive model to explain the 'sleeper united Irelander Catholic' phenomenon, and do so for a number of reasons. First, the two elements of border concern that we focus on are reasonably strongly correlated (0.37) and we wish to include them both in a model predicting conditional Catholics to isolate the more important driver. There are additional possible reasons - other than concerns directly relating to the border why a Catholic may be prompted to support a united Ireland under hard Brexit conditions, including their concerns about rights-protection. For example, some Catholics may be driven by factors relating to party political representation. The Democratic Unionist Party (DUP) had a uniquely powerful position between 2017 and 2019 in buttressing the minority Conservative government. Given the absence of a power-sharing government in Northern Ireland since March 2017 and the absence of Sinn Féin MPs in Westminster (because of the party's abstentionist policy) we suggest that antipathy to how the DUP is representing Northern Ireland may predict support for a united Ireland under Brexit conditions. (The variable we use differentiates between respondents agreeing that the DUP is doing a very bad or fairly bad job at 'representing the interests of people in Northern Ireland during the Brexit negotiations' and those saying it is doing either a (very / fairly) good job or a neither good nor bad job.)

A hard Brexit would represent a deepening separation of Northern Ireland from the Republic. We hypothesize that this may be anathema to highly educated and socially liberal Catholics, especially amid the emergence of a liberal 'progressive' Ireland with respect to same sex 
marriage and abortion compared to the blocking of such policy developments in Northern Ireland, especially by the DUP. We expect that the political profile of conditional Catholic nationalists will be different from the consistent pro-united Ireland nationalists. These 'new' UKEXIT-engineered nationalists are likely to be from typically moderate political stock in terms of identity (self-describing as 'Northern Irish rather than 'Irish') and partisanship (supporting Alliance and the SDLP rather than Sinn Féin). ${ }^{7}$ In other words, that set of Catholics who have typically been politically moderate but who have become irritated by UKEXIT may now align with the consistently hard-core pro-united Ireland nationalists who are strongly 'Irish' and Sinn Féin supporting.

We test these expectations in a multi-nomial logistic regression in which the dependent variable is type of Catholic: consistently pro-united Ireland, consistently pro remaining in the UK, consistently 'doesn't know', and - our main focus - conditional Catholic nationalists, i.e. those who favour a united Ireland under hard UKEXIT conditions. This last group is the dependent variable's reference category in the regression analysis to facilitate an examination of how each of the other types of cultural Catholic differs from this group (i.e. the group against which we compare the other types of Catholics). Consistent with Figures 4 and 5 we find that conditional Catholics are more concerned than consistent proUK Catholics on both border variables, and are as concerned as the consistent pro-united Irelanders on both border variables. However, it is the variable capturing support for protest that is doing most of the predictive work in differentiating the conditional Catholics from the consistent pro-UK Catholics. In short, for the conditional Catholics it is not just that they

\footnotetext{
${ }^{7}$ See McNicholl et al. (2018) on a discussion of identity distinctions and Garry (2016) on the partisan distinction.
} 
find border changes unacceptable, but crucially, the fact that they are willing to support protests against them that distinguishes them from the consistently pro-UK catholics.

$<<$ Table 1 about here $>>$

We also find that it is the socially liberal and degree-educated cultural Catholics that have the greatest propensity to be prompted to become pro-united Ireland under 'hard Brexit conditions', and likewise Catholics who strongly negatively evaluate the DUP's performance in representing Northern Ireland during the UK's negotiations with the EU.

We have identified how the conditional Catholics are different from the consistently pro-UK Catholics, but how are the conditional Catholic nationalists different from their steadfastly pro-united Ireland bedfellows? The answer is that they are likely be supporters of moderate parties (Alliance, Green or SDLP) and are more likely to be Northern Irish rather than Irish identifiers. UKEXIT and the DUP's tactical and strategic response to it are sending liberal, bourgeois, educated Catholics toward the conviction that a reunified Ireland will better reflect their values, and their interests.

\section{Conclusions}

We have sought to understand the potential for significant changes in preferences over Northern Ireland's constitutional future that may occur as a result of the effects of the UK's decision to leave the EU. We have identified a sub-group of Catholics whose acquiesence with Northern Ireland staying in the UK is conditional upon the outcome of the UK's exit from the EU. The potential effect of this exit on north-south border changes is driving the 
possibly significant shift in Catholic opinion towards favoring a united Ireland, but other factors include tertiary education, social views, identity, and evalution of the DUP.

Since our data was collected, the UK's prime minister Teresa May was replaced by Boris Johnson. In October 2019 he negotiated a new Withdrawal Agreement with an amended Northern Ireland Protocol. This 'new' Withdrawal Agreement was essentially the same as the previously rejected one which included a 'Northern Ireland only' backstop (which May then replaced with a UK-wide backstop). This new arrangement is frequently called 'the frontstop' because it will apply in all circumstances, bar one. Northern Ireland would remain in the EU's single market for goods and agricultural products. It would be part of the UK's customs union, de jure, but de facto that border be administered in the Irish sea in accordance with EU law. The exceptional circumstance is if the Northern Ireland Assembly votes to end these arrangements. After the Conservative victory in the UK general election of December 2019 it seems highly likely that this frontsop will go into operation.

This reversion to an NI-only backstop (or frontstop) will move the focus of attention significantly away from the potential hardening of the north-south border to the hardening of the economic east-west border between NI and GB. But the land border question is not over. The Northern Ireland Assembly might vote to end the Protocol though we judge that unlikely, even if the Assembly revives. Moroever, if the UK's negotiations on its future relationships with the EU fail it is possible that the Conservative government might repudiate the Protocol, though it is biding under international law. The salience of the north-south border question therefore remains open to fluctuation, and if it rises again it is likely to cause a significant section of the Catholic community to support Irish reunification. 
Unions, federations and confederations break up for many reasons, but one key reason is non-consensual re-centralization (McGarry and O’Leary 2009). The Brexiteers have justified their exit from the EU to protect "Britain" from European Union centralization. But they may have forgotten that their own project may be seen as unilateral centralization by many of the Northern Irish (and the Scots). The UK's exit is being imposed on Northern Ireland, albeit modified by the Protocol, and on Scotland. The exit of a multi-national member state from the EU confederation without strong support or consent from each component may jeopardize its own union. Attitude change is likely to be particularly acute when the region in question is contested, has endured several decades of ethno-national violence and represents the land border with the confederation. 


\section{References}

Belfast Telegraph. 2019. "Ministers discussed possibility of Irish border poll in event of nodeal Brexit- reports" (January 9)

Connolly, T. 2018. Brexit and Ireland: The Dangers, the Opportunities, and the Inside Story of the Irish Response Dublin: Penguin

Farrell, D., Suiter, J. and C. Harris. 2019. 'Systematizing' constitutional deliberation: the 2016-18 citizens' assembly in Ireland' Irish Political Studies 34(1):113-123

Farrell, D. 2014. “'Stripped Down' or Reconfigured Democracy” West European Politics, 37(2):439-455

Ferriter, D. 2019. The Border: The Legacy of a Century of Anglo-Irish Politics London: Profile Books,

Fournier, F., can der Kolk, H., Carty, K., Blais, A. and J. Rose. 2011. When Citizens Decide: Lessons from Citizen Assemblies on Electoral Reform. Oxford: Oxford University Press.

Fishkin, J. 2018. Democracy When the People Are Thinking: Revitalizing Our Politics Through Public Deliberation Oxford: Oxford University Press.

Ganiel, G. “'Battling in Brussels': The DUP and the European Union.” In K. Hayward and M. Murphy (eds.) The Europeanisation of Party Politics in Ireland, North and South London: Routledge

Garry, J. 2016. Consociation and Voting in Northern Ireland Philadelphia: University of Pennsylvania Press.

Government of the United Kingdom. 1998. The Agreement: Agreement Reached in the Multi-Party Negotiations. 
Katy Hayward \& Mary C. Murphy (2018) The EU's Influence on the Peace Process and Agreement in Northern Ireland in Light of Brexit, Ethnopolitics, 17:3, 276-291, DOI: $10.1080 / 17449057.2018 .1472426$

Leary, Peter. 2016. Unapproved Routes: Histories of the Irish Border, 1922-1972. First edition. ed. Oxford: Oxford University Press.

Lluch, Jaime. 2014. Visions of Sovereignty: Nationalism and Accommodation in Multinational Democracies. Edited by Brendan O'Leary, National and Ethnic Conflict in the 21st Century. Philadelphia: University of Pennsylvania Press.

Maher, Imelda. 2017. "The Common Travel Area: More Than Just Travel." A Royal Irish Academy-British Academy Brexit Briefing (October).

Maillot, A. "Sinn Féin's Approach to the EU: Still more 'Critical' than 'Engaged'?" In K. Hayward and M. Murphy (eds) The Europeanisation of Party Politics in Ireland, North and South London: Routledge

McCrudden, Christopher. 2017a. "An Early Deal-Breaker? EU Citizens' Rights in the UK after Brexit, and the Future role of the European Court of Justice." UK Constitutional Law Association, June 27 2017. http://ukconstitutionallaw.org.

McCrudden, Christopher. 2017b. "The Good Friday Agreement, Brexit, and Rights." $A$ Royal Irish Academy-British Academy Brexit Briefing (October).

McGarry, John. 1998. "Political Settlements in Northern Ireland and South Africa." Political Studies 46 (5):853-70.

McGarry, John, ed. 2001. Northern Ireland and the Divided World: Post-Agreement Northern Ireland in Comparative Perspective. Oxford: Oxford University Press.

McLoughlin, P. "The SDLP and the Europeanization of the Northern Ireland Problem." In K. Hayward and M. Murphy (eds) The Europeanisation of Party Politics in Ireland, North and South London: Routledge 
McNicholl, K., Stevenson, C. and J. Garry. 2018. How the 'Northern Irish' national identity is understood and used by young people and politicians' Political Psychology pp. 119. DOI: $10.1111 /$ pops. 12523

Murphy, M. 2018. Europe and Northern Ireland's Future Agenda Publishing.

O'Leary, Brendan. 2016. "The Dalriada Document: Towards a Multinational Compromise that Respects Democratic Diversity in the United Kingdom." Political Quarterly 87 (4):5618-33.

O'Leary, Brendan. 2019a. A Treatise on Northern Ireland: Colonialism. III vols. Vol. 1. Oxford: Oxford University Press.

O'Leary, Brendan. 2019b. A Treatise on Northern Ireland: Consociation and Confederation. III vols. Vol. III. Oxford: Oxford University Press.

O'Leary, Brendan. 2019c. A Treatise on Northern Ireland: Control. III vols. Vol. II. Oxford: Oxford University Press.

O'Rourke, K. 2019. A Short History of Brexit Pelican

Todd, Jennifer. 2003. The Good Friday Agreement April 10 1998: The Changing Structure of Conflict in Northern Ireland and the Ideal (Written) and Real (Implemented) Good Friday Agreement. Dublin: IBIS.

Young, Robert A. 1995. The Secession of Quebec and the Future of Canada. Montreal \& Kingston: McGill Queen's University Press. 
Figure 1:

'Almost impossible to accept' at north-south border (\%)

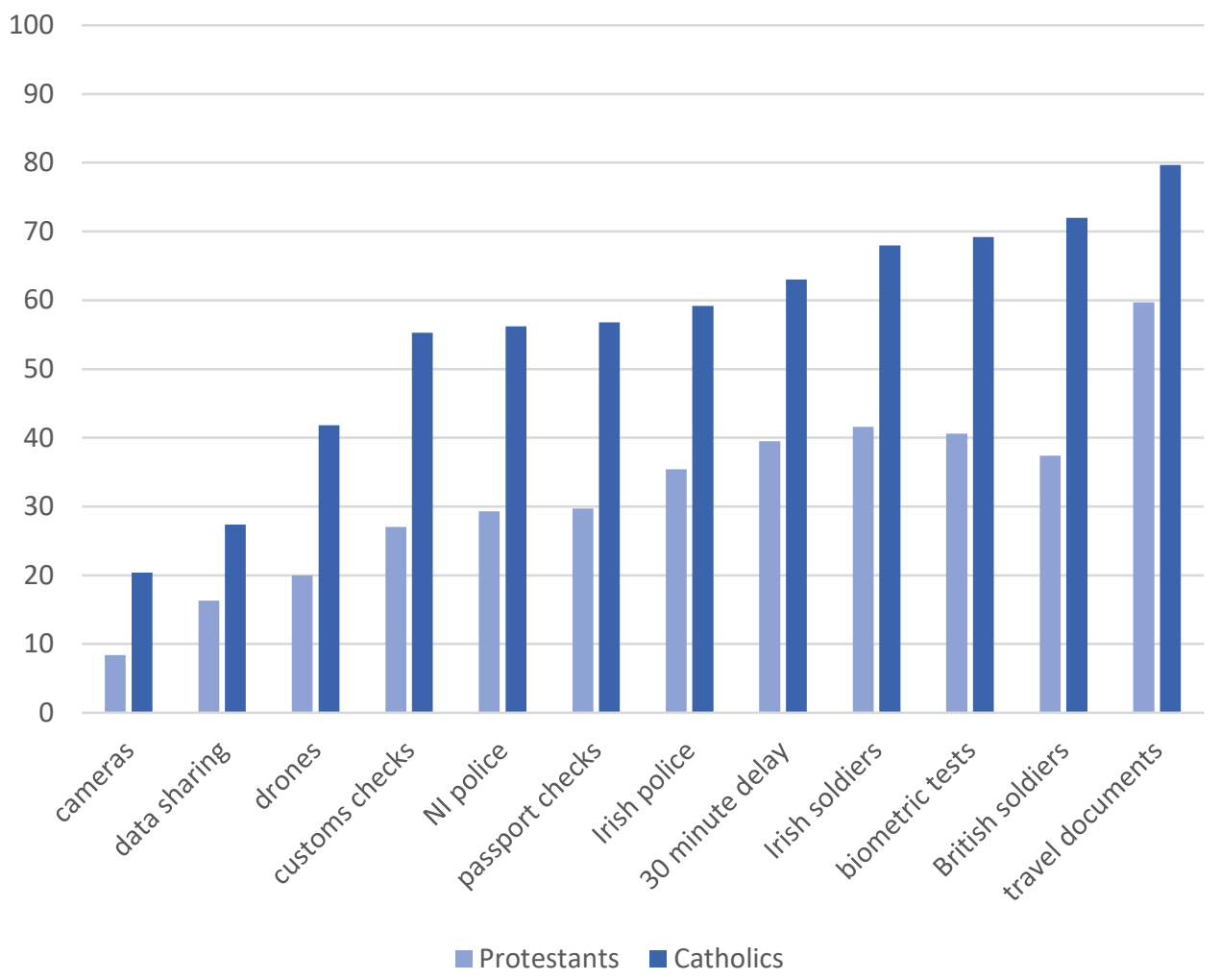


Figure 2:

Fairly or very supportive of different types of protest against northsouth border checks (\%)

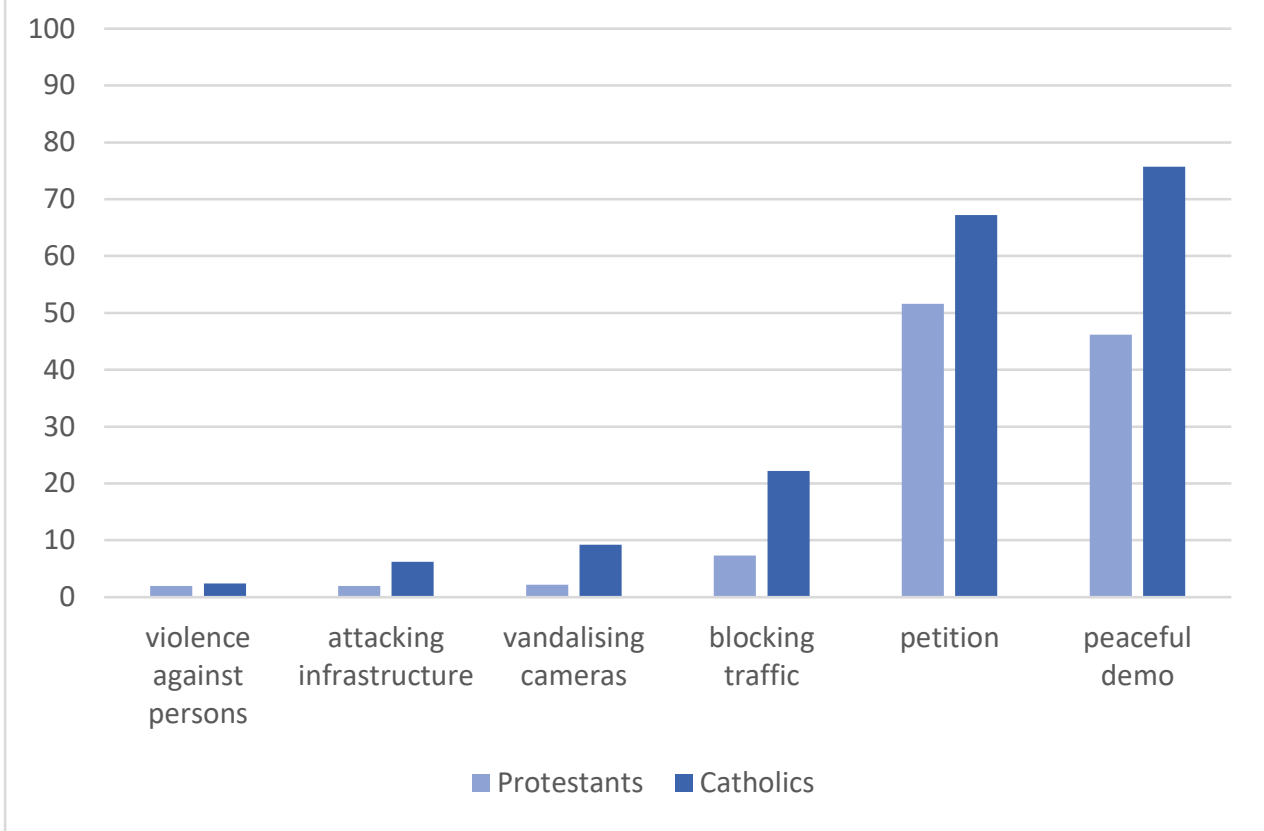




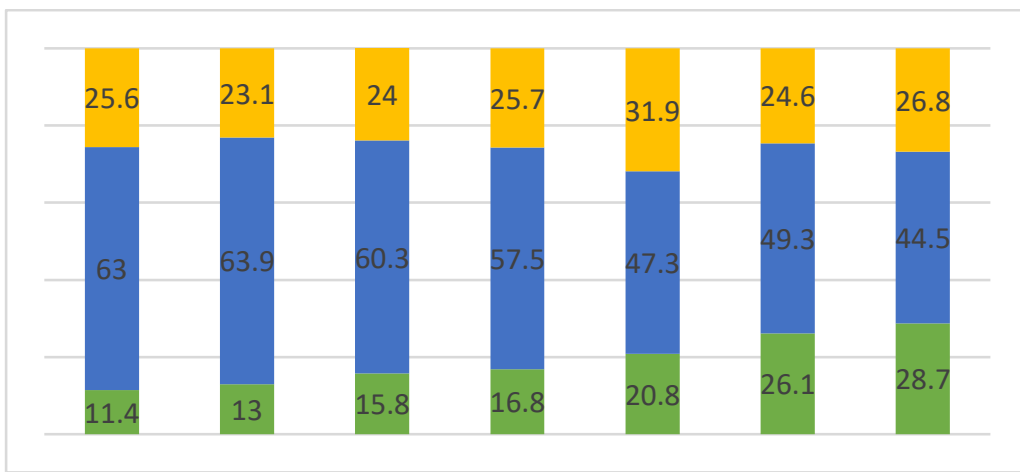

All respondents

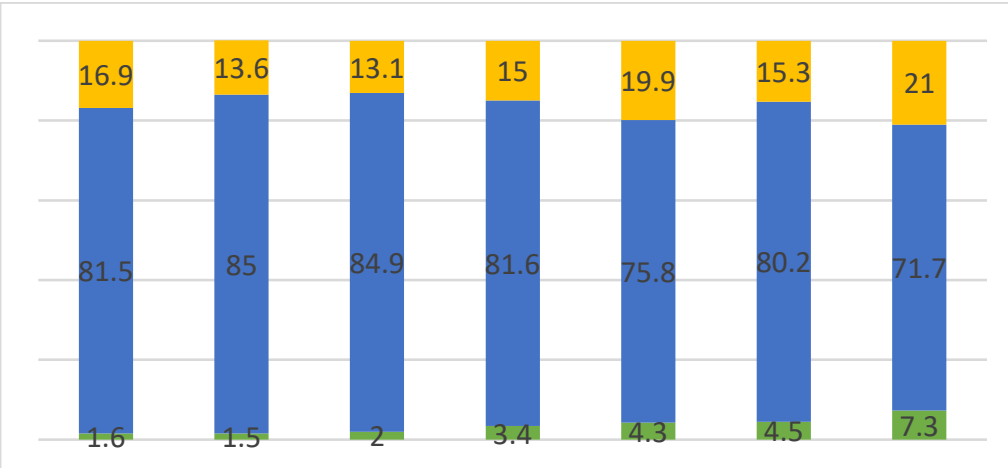

Protestants

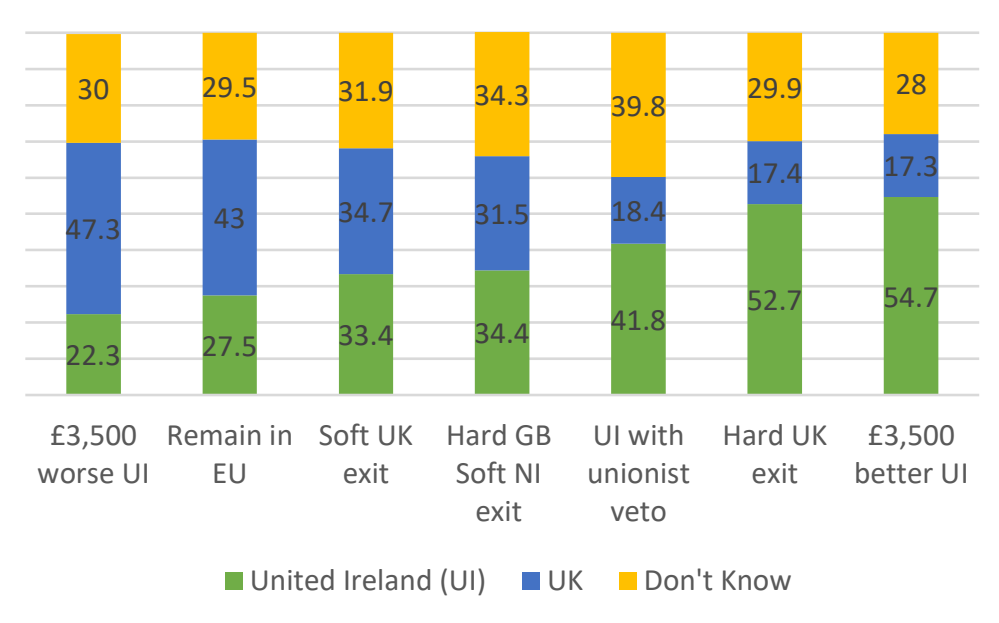

Catholics

Figure 3:

Vote intention in a referendum choice between Northern Ireland staying in the UK or a United Ireland, under different conditions 
Figure 4:

Choosing UK or United Ireland under conditions of a/Remain and b/Hard Brexit, by border change unacceptability

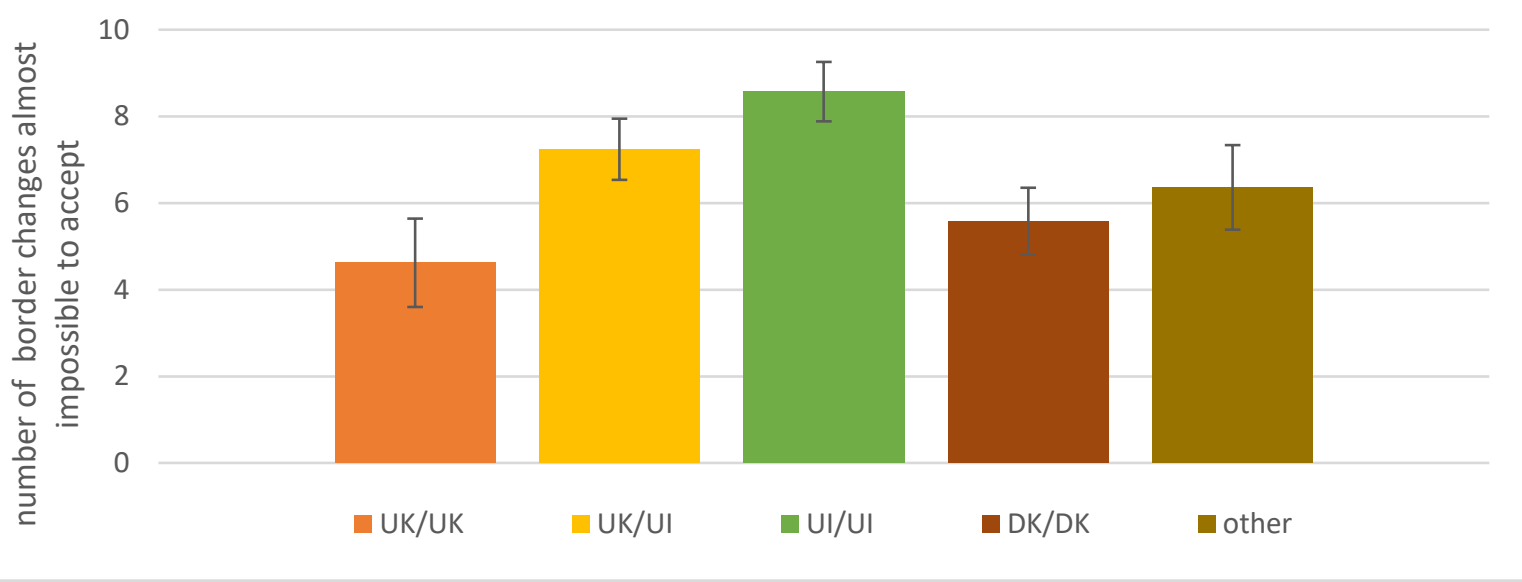


Figure 5:

Choosing UK or United Ireland under conditions of a/Remain and b/Hard Brexit, by support for border protests

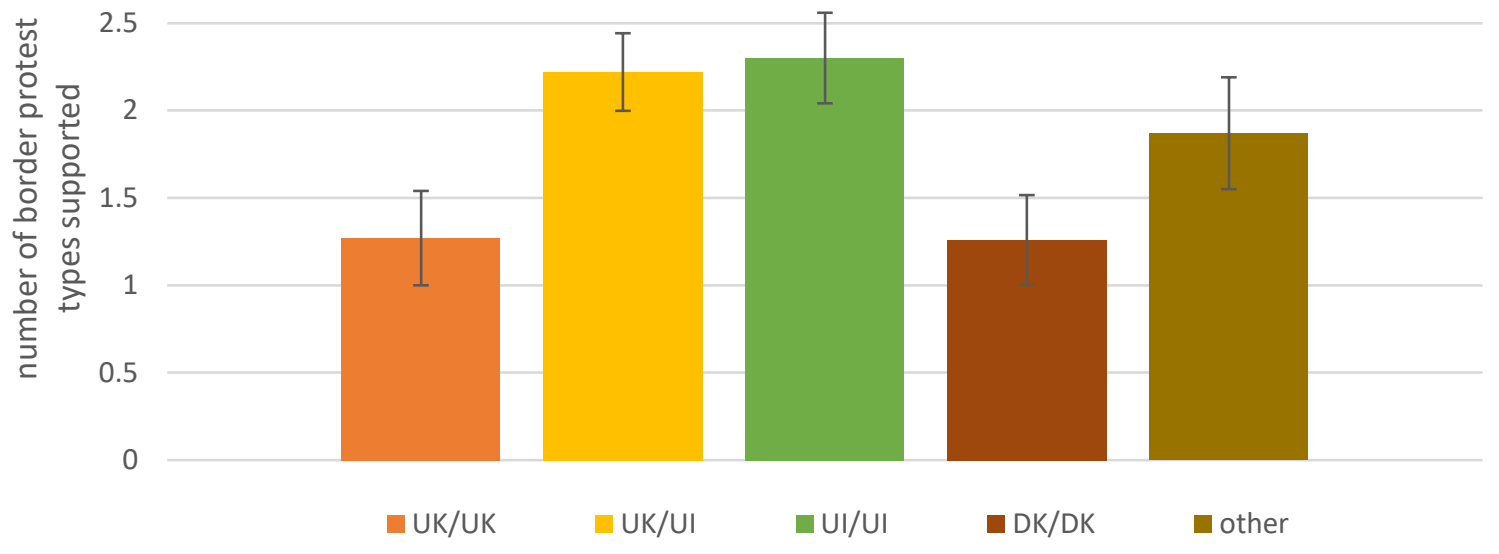


Table 1

Predicting Catholics with pro-United Ireland views that are conditional upon a 'hard Brexit': Multinomial logistic regression

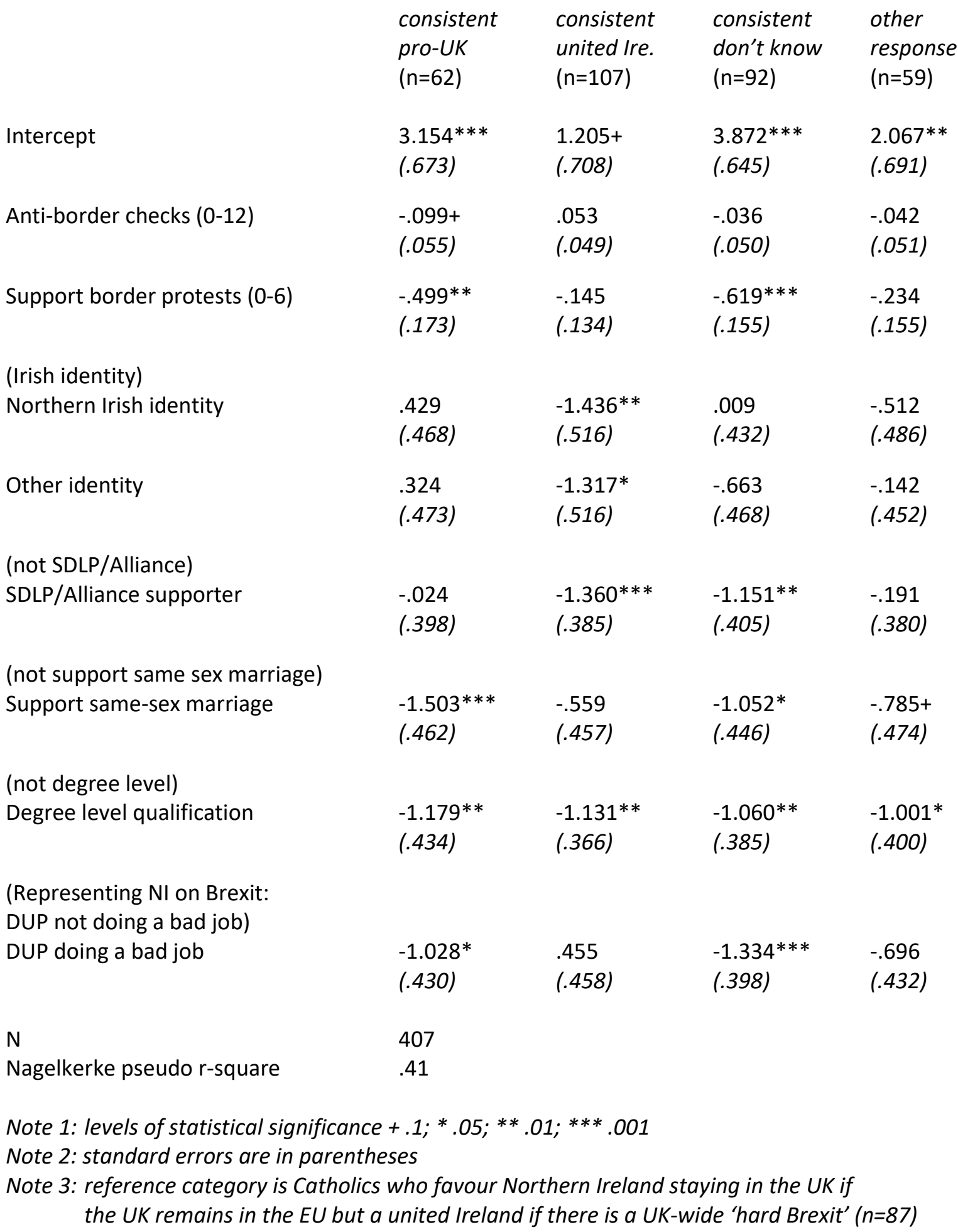

